\title{
Adhalin Gene Mutations in Patients with Autosomal Recessive Childhood Onset Muscular Dystrophy with Adhalin Deficiency
}

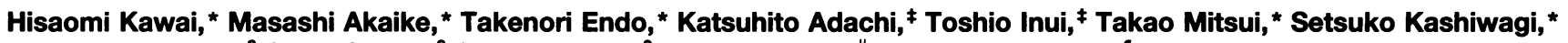 \\ Tsutomu Fujiwara, ${ }^{5}$ Shiro Okuno, ${ }^{8}$ Sadahito Shin, ${ }^{8}$ Kazuo Miyoshi," Kevin P. Campbell," Hiroki Yamada, ${ }^{\star *}$ \\ Teruo Shimizu, ${ }^{\star *}$ Kiichiro Matsumura, ${ }^{\star \star}$ and Shiro Saito* \\ ${ }^{*}$ First Department of Internal Medicine, School of Medicine, The University of Tokushima, Tokushima 770, Japan; ${ }^{\ddagger}$ Department of \\ Neurology, National Sanatorium Tokushima Hospital, Oegun, Tokushima 776, Japan; ${ }^{8}$ Laboratory of Gene Research, Otsuka \\ Pharmaceutical Company, Tokushima 771-01, Japan; "The University of Tokushima, Tokushima 770, Japan; ' Howard Hughes Medical \\ Institute, The University of Iowa College of Medicine, Iowa City, Iowa 52242; and **Department of Neurology, School of Medicine, \\ Teikyo University, Tokyo 173, Japan
}

\begin{abstract}
Homozygous adhalin gene mutations were found in three patients from two consanguineous families with autosomal recessive childhood onset muscular dystrophy. Muscle biopsies from patients in each family showed complete absence of adhalin. Sequencing of adhalin cDNA prepared from skeletal muscle by reverse transcription PCR demonstrated a cytosine to thymidine substitution at nt 229 in the patient in family 1 and an adenine to guanine substitution at nt $\mathbf{4 1 0}$ and a 15-base insertion between nt 408 and 409 in the two patients in family 2 . Sequencing of genomic DNA prepared from peripheral blood leukocytes by PCR confirmed these mutations. The parents in each family were found to be heterozygous for the respective mutations. These adhalin gene mutations are presumed to be responsible for the absence of adhalin in the skeletal muscle. Adhalin deficiency likely causes disruption of the muscle cell membrane, resulting in dystrophic changes in the skeletal muscle similar to dystrophin deficiency in Duchenne muscular dystrophy. (J. Clin. Invest. 1995. 96:1202-1207.) Key words: autosomal recessive childhood onset muscular dystrophy • adhalin gene - missense mutation - nucleotide insertion - muscle membrane cytoskeleton
\end{abstract}

\section{Introduction}

Patients with Duchenne-like muscular dystrophy showing autosomal recessive inheritance have been reported for several decades (1-7). Often referred to as severe childhood autosomal recessive muscular dystrophy $(\text { SCARMD })^{1}(8)$, it is thought to be genetically heterogeneous $(9-11)$, with many different

Address correspondence to Hisaomi Kawai, MD, First Department of Internal Medicine, School of Medicine, The University of Tokushima, 3-18-15 Kuramoto, Tokushima 770, Japan. Phone: 886-31-3111 x3204; FAX: 886-33-7121.

Received for publication 23 February 1995 and accepted in revised form 24 May 1995.

1. Abbreviations used in this paper: CK, creatine kinase; RT, reverse transcription; SCARMD, severe childhood autosomal recessive muscular dystrophy.

J. Clin. Invest.

(C) The American Society for Clinical Investigation, Inc. 0021-9738/95/09/1202/06 \$2.00

Volume 96, September 1995, 1202-1207 primary biochemical defects. Deficiency of adhalin (a 50-kD dystrophin-associated glycoprotein) in the skeletal muscle has been found in several families with SCARMD (12-16). Recently, complete absence of adhalin in skeletal muscle and missense mutations in the adhalin gene were identified in a single French family with autosomal recessive muscular dystrophy which was less clinically severe than SCARMD (17). Here we report two consanguineous Japanese families with childhood onset muscular dystrophy where we found complete absence of adhalin in the skeletal muscle. This prompted us to analyze the adhalin gene of these patients for possible mutations.

\section{Methods}

\section{Subjects}

Three Japanese patients with SCARMD from two unrelated consanguineous families and five unaffected family members were studied. Muscle biopsies were obtained from the three patients and peripheral blood was obtained from them and five family members including their parents.

\section{Methods}

Immunohistochemical analysis of biopsied skeletal muscle (12, 16). Cryosections (7-8 $\mu \mathrm{m})$ of biopsy specimens of skeletal muscle were blocked for $1 \mathrm{~h}$ with $5 \%$ bovine serum albumin in phosphate-buffered saline (PBS), $\mathrm{pH} 7.4$, and then incubated for $2 \mathrm{~h}$ with primary antibodies at the following dilutions: monoclonal antibody VID $3_{1}$ against adhalin, 1:50; monoclonal antibody $\mathrm{VIA}_{2}$ against dystrophin, neat; affinitypurified sheep antiserum against $\alpha$-dystroglycan, neat: affinity-purified sheep antiserum against $\beta$-dystroglycan, 1:20; affinity-purified sheep antiserum against the $59-\mathrm{kD}$ dystrophin-associated protein, 1:20; affinity-purified sheep antiserum against the $35-\mathrm{kD}$ dystrophin-associated glycoprotein, 1:20. In the case of mouse primary antibodies, cryosections were incubated with 1:200 diluted fluorescence-conjugated antimouse IgG (Boehringer-Mannheim Corp., Indianapolis, IN) for $1 \mathrm{~h}$. In the case of sheep primary antibodies, cryosections were incubated with 1:500 diluted biotinylated anti-sheep IgG (Vector Laboratories, Burlingame, CA) for $1 \mathrm{~h}$, followed by a 30-min incubation with 1:1,000 diluted fluorescence-conjugated streptoavidin (Jackson ImmunoResearch Labs, Inc., West Grove, PA). Each incubation was followed by rigorous washing with PBS.

Analysis of the nucleotide sequence of adhalin cDNA. Total RNA was isolated from 50-mg samples of biopsied skeletal muscle using an RNA Isolation $\mathrm{Kit}^{\circledast}$ (Stratagene, La Jolla, CA) (18). Six sets of primers for reverse transcription-PCR (RT-PCR) (19) were designed to cover the entire cDNA based on the adhalin cDNA sequence reported by Roberds et al. (17). The primers used were as follows: set a, 5'-CCATGGCTGAGACACTCTTC-3' and 5'-TGGGTGTAGCGGAGCCAC$3^{\prime}$; set b, 5'-AGGGACACCCAGACCTGC-3' and 5'-AGGAACTCGGCTTGGTATGG-3'; set c, 5'-GAGGTCACAGCCTACAATCG-3' and 5'-TCCAAGGCAGAGGTGACGT-3'; set d, 5'-GGAGAGCTTCAGCTGCTCA-3' and 5'-CTGACTTATCCACCAGGGTC-3'; set e, 
5'-TCCGCGTTGACTGGTGCAAT-3' and 5'-ATCTGGATGTCGGAGGTAGC-3'; set f, 5'-AGGGAAGGCTGAAGAGAGAC-3' and 5'-AGGATGAAGTCAGGGCTGGA-3'.

RT-PCR was performed in $20 \mu \mathrm{l}$ of reaction mixture containing 1 $\mu \mathrm{g}$ of RNA sample, $50 \mathrm{mM}$ Tris- $\mathrm{HCl}(\mathrm{pH} 8.3), 75 \mathrm{mM} \mathrm{KCl}, 3 \mathrm{mM}$ $\mathrm{MgCl}_{2}, 1 \mathrm{mM}$ of each dNTP, $100 \mathrm{pmol}$ of random hexamer, $40 \mathrm{U}$ of ribonuclease inhibitor and $200 \mathrm{U}$ of Moloney murine leukemia virus reverse transcriptase (GIBCO BRL, Gaithersburg, MD). The reaction was carried out at $23^{\circ} \mathrm{C}$ for $10 \mathrm{~min}$ and $37^{\circ} \mathrm{C}$ for $60 \mathrm{~min}$, followed by denaturation at $95^{\circ} \mathrm{C}$ for $5 \mathrm{~min}$. For amplification, $80 \mu \mathrm{l}$ of a mixture containing $10 \mathrm{mM}$ Tris- $\mathrm{HCl}(\mathrm{pH} 8.3), 50 \mathrm{mM} \mathrm{KCl}, 1.5 \mathrm{mM} \mathrm{MgCl}_{2}, 5$ $\mathrm{U}$ of recombinant Taq DNA polymerase (Takara Co., Ohtsu, Japan), and $30 \mathrm{pM}$ of primers was added. PCR (20) was performed using the Program Temp Control System PC-700 (ASTEC, Fukuoka, Japan). The amplification profile consisted of initial denaturation at $94^{\circ} \mathrm{C}$ for $2 \mathrm{~min}$, 35 cycles of denaturation at $94^{\circ} \mathrm{C}$ for $1 \mathrm{~min}$, primer annealing at $55^{\circ} \mathrm{C}$ for $1 \mathrm{~min}$, extension at $72^{\circ} \mathrm{C}$ for $1 \mathrm{~min}$, and final extension at $72^{\circ} \mathrm{C}$ for $7 \mathrm{~min}$. The six fragments of PCR products were separated by electrophoresis in $2 \%$ agarose gel and then excised and purified with glass powder (Geneclean Kit ; Bio 101, La Jolla, CA).

Each purified PCR product was subcloned into a plasmid vector, pCR II, using a TA Cloning System Kit (Invitrogen, San Diego, CA) (21). The DNA sequences of the clones were determined by the fluorescence-based dideoxy termination method $(22,23)$ using an automated fluorescence sequencer (A.L.F. DNA sequencer; Pharmacia AB, Uppsala, Sweden ).

Analysis of the nucleotide sequence of genomic DNA. Genomic DNA was isolated from peripheral blood leukocytes by proteinase $\mathrm{K}$ digestion and phenol/chloroform extraction (24). The regions corresponding to mutations found in adhalin cDNA were amplified by PCR using the following pairs of primers: 5'-TCTGAGCCTTCCTGAGCATGT-3' and 5'-CAATGACCTGGAGCCCACGAT-3' for family 1 and 5'-TGGAGATTGGGGACCCAGAA-3' and 5'-TTGAGCAGCTGAAGCTCTCC-3' for family 2. PCR was performed in $50 \mu$ lof reaction mixture containing $200 \mathrm{ng}$ of genomic DNA, $10 \mathrm{mM}$ Tris- $\mathrm{HCl}(\mathrm{pH}$ $8.3), 50 \mathrm{mM} \mathrm{KCl}, 1.5 \mathrm{mM} \mathrm{MgCl}_{2}, 0.2 \mathrm{mM}$ dNTPs, 15 pmol of primers, and $2.5 \mathrm{U}$ of recombinant Taq DNA polymerase. The amplification profile consisted of initial denaturation at $94^{\circ} \mathrm{C}$ for $2 \mathrm{~min}, 35$ cycles of denaturation at $94^{\circ} \mathrm{C}$ for $1 \mathrm{~min}$, annealing at $55^{\circ} \mathrm{C}$ for $1 \mathrm{~min}$ and extension at $72^{\circ} \mathrm{C}$ for $1 \mathrm{~min}$, and final extension at $72^{\circ} \mathrm{C}$ for $7 \mathrm{~min}$. Each PCR product was subcloned into PCR II and sequenced using an A.L.F. DNA sequencer.

In addition to genomic DNA samples from patients and their family members, genomic DNA samples were prepared from 75 unrelated normal individuals. The regions corresponding to the two mutations were amplified and sequenced by the same procedure in 75 patients, one subcloned DNA for each individual. Furthermore, PCR products of genomic DNA covering the site of 15-base insertion (see Results) were run in $7.5 \%$ polyacrylamide gel to screen for the insertion.

\section{Results}

\section{Clinical data on the patients}

Family 1; patient 1 . This patient is a 23 -yr-old female whose parents are first cousins (Fig. 1, Family 1). She first walked at $15 \mathrm{mo}$. She showed an unsteady gait at $3 \mathrm{yr}$ of age with subsequent progressive motor deterioration of the lower extremities. At $8 \mathrm{yr}$ of age, she had difficulty in standing up from a sitting position but she could walk without assistance. At $11 \mathrm{yr}$, she could walk with support but she could not stand up unaided. She has been confined to a wheelchair since she was $15 \mathrm{yr}$ old.

Her intelligence is normal. She has generalized muscle wasting and muscle weakness, predominantly in the pelvic-girdle region. Her calves appear hypertrophic but her muscles are soft. Deep tendon reflexes of the legs are absent or hypoactive.

Her serum creatine kinase (CK) level is $840 \mathrm{IU} /$ liter (nor- mal level, $<200 \mathrm{IU} /$ liter), but was 3,606 IU/liter at $11 \mathrm{yr}$ of age. A chest $\mathrm{x}$-ray showed no evidence of cardiomegaly. An electrocardiogram (ECG) showed $\mathrm{QS}$ in lead $\mathrm{aV}_{\mathrm{L}}$, but an echocardiogram showed no abnormality. A CT scan of her muscles at $11 \mathrm{yr}$ of age revealed remarkably low density predominantly in the flexor and adductor muscles of the thighs and the lower legs. A needle electromyogram (EMG) showed a mild myopathic pattern. Histological examination of the left vastus lateralis muscle at $11 \mathrm{yr}$ of age showed muscle fiber necrosis and degeneration with a small number of regenerating fibers. Some opaque fibers were observed, but fewer than in Duchenne muscular dystrophy. Muscle fibers were well differentiated.

Immunohistochemical analysis demonstrated the complete absence of adhalin (Fig. 2), despite nearly normal expression of dystrophin in the sarcolemma (Fig. 2), and reduced stainings of other dystrophin-associated proteins (data not shown).

Her parents are asymptomatic and a younger sister is healthy. Their serum CK activities are normal.

Family 2; patient 1. This patient is a 56-yr-old female whose parents were first cousins (Fig. 1, Family 2). She started to walk at 18 mo of age, but at $5 \mathrm{yr}$ of age she had difficulty in running and often fell. At 9 yr of age she could not climb up stairs without a handrail, and at $10 \mathrm{yr}$ of age she had a waddling gait. She was unable to walk by herself at $13 \mathrm{yr}$ of age. At 30 $\mathrm{yr}$ of age, she was unable to remain in a sitting position. She has been restricted to bed since the age of 35 . At $46 \mathrm{yr}$ of age she received a tracheotomy for respiratory failure due to weakness of her respiratory muscles.

Her intelligence is normal. She has marked and generalized muscle wasting, but facial muscles are largely spared. She can barely move her fingers and toes, and deep tendon reflexes of her extremities are absent.

Her serum CK activity is $400 \mathrm{IU} /$ liter (normal level, $<200$ IU/liter). A chest $x$-ray showed no cardiomegaly. An ECG showed a tall $R$ in $V_{1}$, and $Q S$ in leads $I$ and $a V_{L}$, but an echocardiogram showed no abnormality. A needle EMG of the leg muscles showed a severe myopathic pattern. Histological examination of a biopsy specimen of the anterior tibial muscle showed dystrophic changes, but few opaque fibers. Type I fibers were predominant.

Immunohistochemical examination of skeletal muscle showed complete absence of adhalin (Fig. 2) but the presence of dystrophin (Fig. 2).

Family 2; patient 2. This patient is a 31-yr-old female whose parents are first cousins (Fig. 1, Family 2). She started to walk at 18 mo of age, but at $5 \mathrm{yr}$ of age she experienced difficulty in running and often fell. From 7 yr old, she had difficulties in climbing stairs unassisted. At $14 \mathrm{yr}$ of age she was unable to walk and was restricted to a wheelchair. Ankylosis of the knee and foot joints was noted.

Her intelligence is normal. Muscle wasting is diffuse and most prominent in the thighs. Her facial muscles are relatively well preserved. Deep tendon reflexes of the extremities are absent.

Her serum CK activity is $680 \mathrm{IU} /$ liter and her serum myoglobin level is $128 \mathrm{ng} / \mathrm{ml}$ (normal value, $<60 \mathrm{ng} / \mathrm{ml}$ ). A chest $\mathrm{x}$-ray showed no apparent cardiomegaly. An ECG showed QS in lead $\mathrm{a} V_{\mathrm{L}}$, but an echocardiogram showed no abnormality. An needle EMG gave a typical myopathic pattern. Histological examination of the anterior tibial muscle showed severe dystrophic changes without opaque fibers and no type I fiber predominancy. 
Family 1

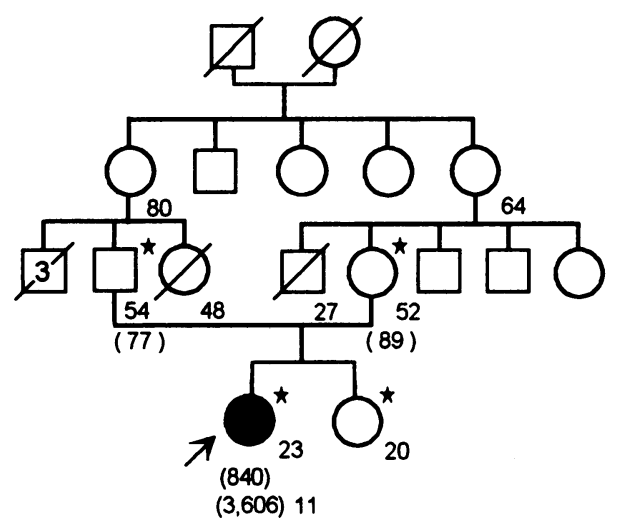

Family 2

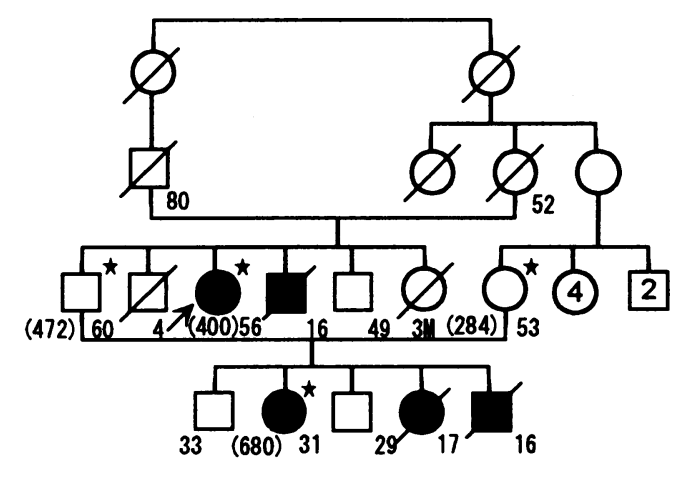

Figure 1. Family trees of family 1 and family 2 . In both families, the parents of the patients were first cousins. In family 1 , serum CK activity (normal value, $<200 \mathrm{IU} /$ liter) was elevated in the patient but not in the parents and the younger sister. The CK activities at $23 \mathrm{yr}$ of age (840 $\mathrm{IU} /$ liter) and at $11 \mathrm{yr}$ of age (3,606 IU/liter) are shown below the symbol of the patient. In family 2, patient 1 (proband) is indicated by an arrow. Three deceased patients and patient 2 had similar muscle symptoms to those of the proband. Serum CK activity was slightly elevated in patients 1 and 2 and in the parents of patient 2. The patients are shown by solid circles (female) or solid squares (male) and those that we examined are shown by stars. Numbers beside symbols for family members show ages and those in parentheses indicate serum CK activities. Figures with open circles and two open squares indicate values for siblings of the same sex. $M$, month; oblique line, deceased.

Immunohistochemical examination showed the absence of adhalin (Fig. 2) but the presence of dystrophin.

Her parents, an elder brother, and a younger brother were asymptomatic. The serum CK activity of her father was 772 IU/liter and that of her mother was $284 \mathrm{IU} /$ liter.

\section{Base sequence of cDNA for adhalin}

Family 1; patient 1. The full base sequences of each cDNA fragment amplified by RT-PCR and subcloned by ligation (20) were homologous to those of normal cDNA, except for that of fragment 2 amplified by primer set $b$. This fragment had a base substitution of $\mathrm{C}$ to $\mathrm{T}$ at nucleotide (nt) 229 (Fig. $3 \mathrm{~b}$ ), which was expected to result in replacement of Arg by Cys in codon 77 (Arg77Cys) of adhalin.

Family 2; patient 1 . The nucleotide sequences of all the cDNA fragments amplified by the same procedure as for patient 1 were homologous with those of normal cDNA, except for that of fragment 3 , which was amplified by primer set $\mathrm{c}$. Nucleotide sequencing of fragment 3 revealed a base substitution of $A$ to $G$ at nt 410 and also an insertion of 15 nucleotides ( $5^{\prime}$ CCTGGTGCGCAGCCA-3') between nt 408 and nt 409 (Fig. $3 d$ ). The substitution resulted in replacement of Glu by Gly
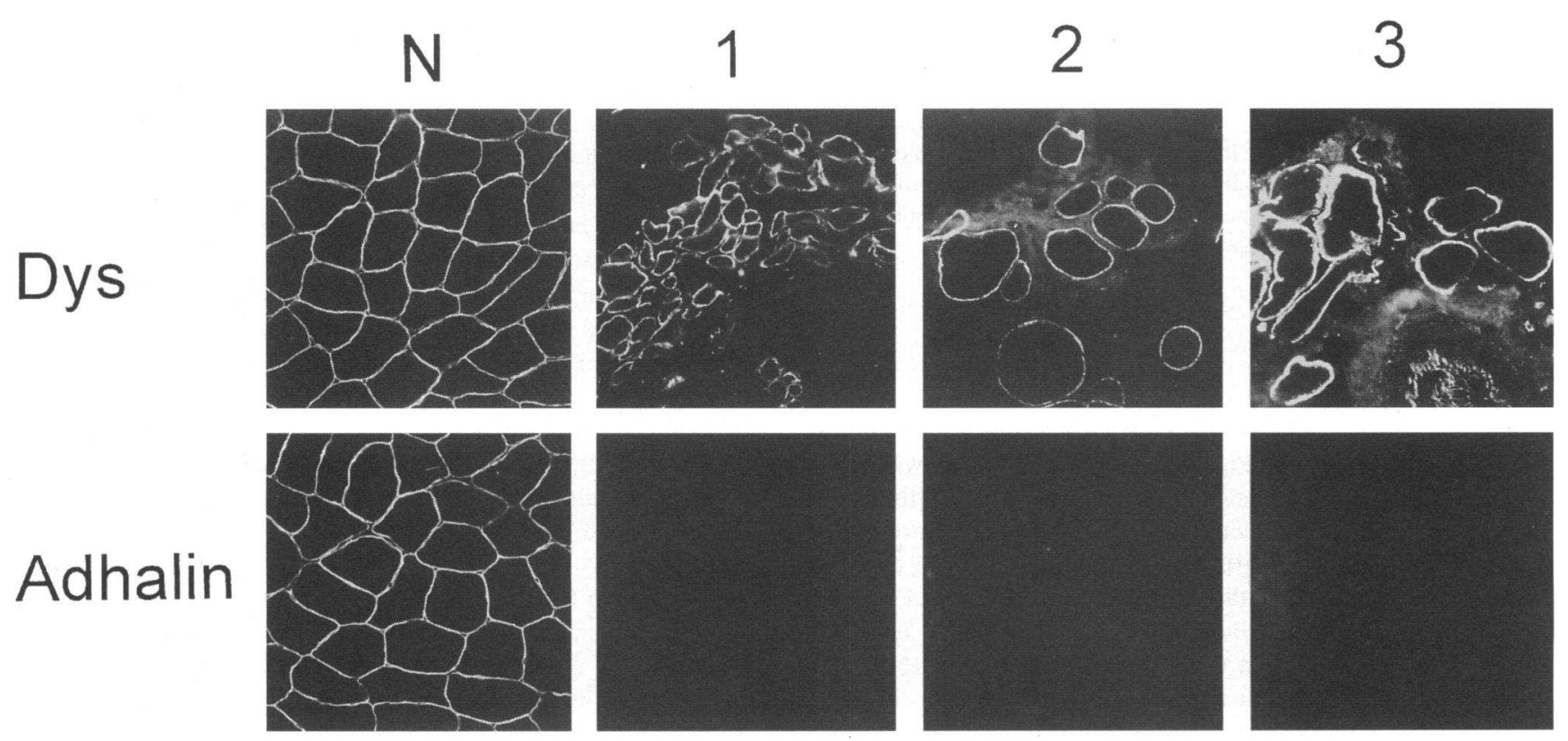

Figure 2. Immunohistochemical analysis of adhalin and dystrophin (Dys) in biopsied skeletal muscle of each patient. Dystrophin was clearly detected, but adhalin (a 50-kD DAG) was undetectable in the skeletal muscle cells of the three patients. $N$, normal control. 1 , family 1 ; patient 1 . 2, family 2 ; patient 1 . 3, family 2 ; patient 2 . 
(a)

Normal

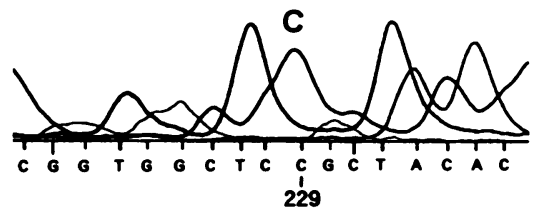

(b)

Family 1

(patient 1)

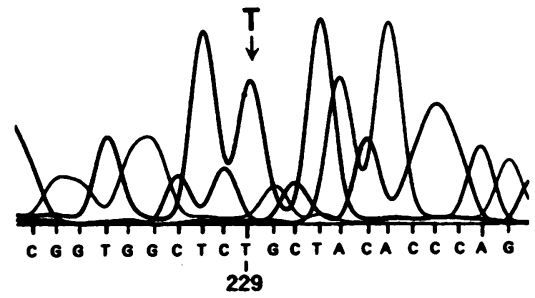

(c)

Normal

(d)

Family 2

(patient 1)

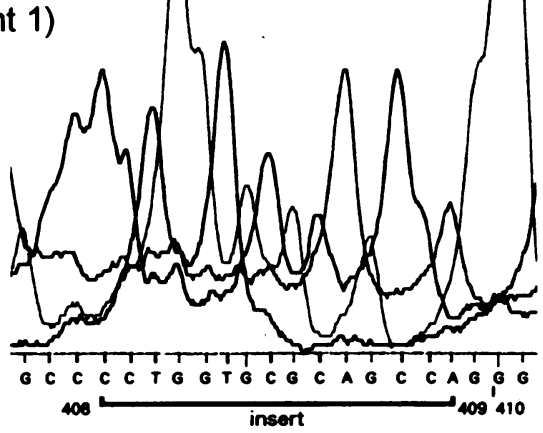

Figure 3. Nucleotide sequences of adhalin cDNA in patient 1 of family 1 and patient 1 of family 2 obtained with an automated sequencer. Results of normal controls are shown in $a$ and $c$, respectively. In patient 1 of family 1 , cytosine $(C)$ at nt 229 was replaced by thymidine $(T)(b)$. In patient 1 of family 2 , adenine $(A)$ at nt 410 was changed to guanine $(G)$, and in addition, a 15-base DNA fragment was inserted between nt 408 and nt $409(d)$. in codon 137 (Glu137Gly). The inserted DNA fragment encoded a peptide with five amino acids, Pro-Gly-Ala-Gln-Pro, and the same sequence was found downstream of this mutation from nt 414 to nt 428 .

Family 2; patient 2. The same results were obtained as for patient 1.

\section{Genomic DNA sequences for adhalin}

Family 1; patient 1. Analysis of the nucleotide sequence of the genomic DNA fragment corresponding to the mutation site in cDNA revealed the same mutation of $C$ to $T$ as in cDNA at nt 229 (data not shown). In this patient, the same nucleotide substitution was identified in all 10 subcloned DNA fragments examined.

Family members in family 1 . Genomic DNA of the father of patient 1 showed the same base substitution in three of nine subcloned genomic DNA fragments, while that of her mother showed the same substitution in two of five DNA samples. No mutation at nt 229 was detected in 10 subcloned DNA samples from the patient's younger sister.

Family 2; patients 1 and 2. Substitution of $\mathrm{G}$ for $\mathrm{A}$ at $\mathrm{nt}$ 410 in the genomic DNA fragment was identified. In addition, an insertion of 15 bases was found between nt 408 and nt 409 in both patients. The base sequence of the inserted DNA was 5'CCTGGTGCGCAGCCA-3' (Fig. 4). All 10 subcloned DNA fragments of the amplified genomic DNA from patients 1 and 2 had the same mutations.

Family members in family 2 . The same nucleotide substitution from $A$ to $G$ at $n t 410$ and an insertion of 15 bases $5^{\prime}$ CCTGGTGCGCAGCCA-3' were found in three of eight subcloned DNA samples of the father of patient 2 (brother of patient 1), and in three of seven DNA samples of her mother (cousin of patient 2 ).

\section{Summary of mutations in the families}

The changes from $\mathrm{C}$ to $\mathrm{T}$ in family 1 (patient 1 ) and from $\mathrm{A}$ to $G$ with a 15-base insertion in family 2 (patients 1 and 2) are shown in Fig. 4.

Neither of these mutations were found by sequencing the subcloned PCR products in 75 normal subjects, and no such

Family 1

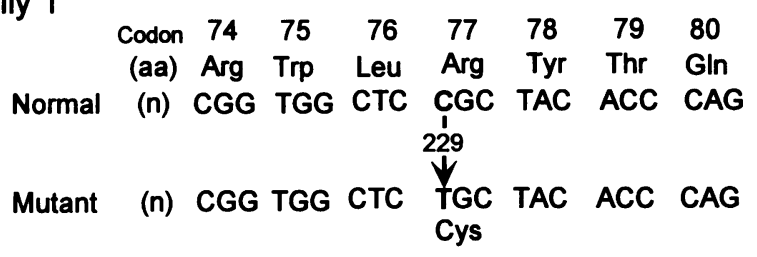

Family 2

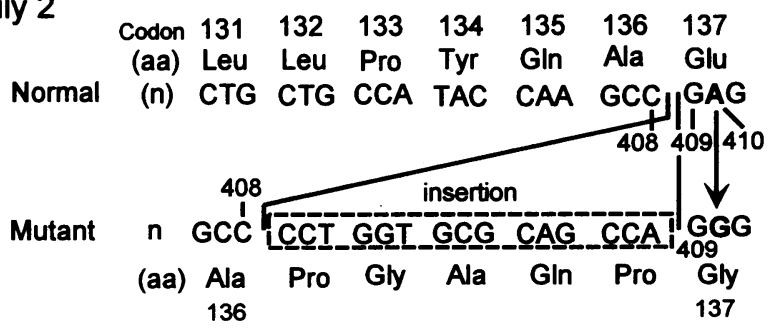

Figure 4. Summary of the mutations in the adhalin gene and the expected substitution of amino acids of adhalin in the two families. Nucleotide $(n)$ and amino acid ( $a a$ ) sequences around the positions of the mutations are shown. In family 1 , a mutation of $C$ to $T$ at nt 229 was identified, resulting in the substitution Arg77Cys. In family 2, a mutation A to $\mathbf{G}$ at $\mathrm{nt} 410$ resulting in the substitution Glu137Gly was detected. In addition, a 15-base insertion between nt 408 and nt 409 was observed. Figures above or beneath nucleotides indicate nucleotide numbers. 
nucleotide insertion was detected in the PCR products in 150 normal subjects by abnormal mobility on polyacrylamide gel electrophoresis.

\section{Discussion}

We have shown both immunocytochemical deficiency of adhalin in skeletal muscle biopsies and homozygous mutations of the adhalin gene in our two Japanese families with childhood onset muscular dystrophy. Very recently, Roberds et al. (17) found missense mutations in the adhalin gene in a French family with autosomal recessive muscular dystrophy which was clinically less severe than SCARMD. Interestingly, the affected siblings in this family were compound heterozygotes for two different mutant adhalin genes.

Our patients were carrying the diagnosis of malignant limbgirdle muscular dystrophy according to the criteria proposed by Miyoshi et al. $(6,7,25)$ which is analogous to the SCARMD disorder. Briefly, symptoms due to muscle weakness developed by $5 \mathrm{yr}$ of age; muscle weakness and wasting were predominant in the proximal muscles and regions of the pelvic girdle; dystrophic changes were detected by histological examination of skeletal muscles; serum CK activity was markedly elevated in young patients and moderately elevated in older patients; the consanguineous parents in both families strongly support an autosomal recessive mode of inheritance.

In the patient of family 1 , we found a single base substitution of $\mathrm{C}$ for $\mathrm{T}$ in the adhalin gene, and in the patients of family 2 we found a single base replacement of A for $\mathrm{G}$ associated with an insertion of a 15-base DNA fragment. The presence of the same base sequence near the insertion site suggests duplication of part of the gene in family 2. These gene mutations were homozygous in the patients but heterozygous in their parents, indicating autosomal recessive inheritance. The absence of mutation of the gene in the younger sister of patient 1 is consistent with this mode of inheritance.

The adhalin molecule has a large extracellular domain containing two potential sites for $\mathrm{N}$-linked glycosylation $(17,26)$. The missense mutations found in our families were located in the region encoding the middle portion of the extracellular domain $(17,26)$. The amino acids substituted in our families are conserved between humans and rabbits $(17,26)$. The resulting amino acid substitutions are expected to reduce the hydrophilicity of the protein, and furthermore the substitution of Arg by Cys with a sulfhydryl radical (-SH) and the insertion of five amino acids would probably affect the secondary and tertiary structures of adhalin. These could disturb its interaction with other membrane-associated proteins or the components of the basal lamina $(16,26-30)$. It is also conceivable that alteration of the higher order structure of mutant adhalin may cause its rapid degeneration. Interestingly, the missense mutations identified in a French family were also located in the middle portion of the extracellular domain of the adhalin molecule. In this family, which showed a milder phenotype than those of our families, mutations in the adhalin gene caused Arg293His in one allele and Val175Ala in the other allele (17). Together, these findings suggest that different sites or types of mutation in the adhalin gene may cause adhalin-deficient muscular dystrophy of various clinical severities. More extensive genotype/ phenotype studies are required on this problem.

Our patients did not suffer from severe cardiac dysfunction or mental retardation. ECGs showed only mild abnormalities compared with those in patients with Duchenne muscular dystrophy $(31,32)$ with similar grades of muscle dysfunction, and echocardiograms showed no abnormalities in our patients. Indeed, patient 1 in family 1 showed no symptoms of cardiac failure even at 56 yr old. Recently, McNally et al. (33) reported that adhalin mRNA from cardiac muscle is shorter than that from skeletal muscle and lacks the base sequence encoding the transmembrane domain. The less severe cardiac dysfunction in some patients with adhalin-deficient muscular dystrophy may be related to lower expression of the adhalin gene in cardiac muscle and/or the presence of a different isoform of adhalin in cardiac muscle. The absence of mental retardation in these patients is most likely explained by the absence of adhalin expression in the brain (26).

\section{Acknowledgments}

This work was supported by a Research Grant (5A-2) for Nervous and Mental Disorders from the Ministry of Health and Welfare of Japan, Grants-in-Aid for Scientific Research on Priority Areas, for Scientific Research (05454262, 06454280, 0670670, and 06770463) and Scientific Research on Developmental Areas (05557037) from the Ministry of Education, Science and Culture of Japan, and Grants from the Nitoh Foundation, Uehara Memorial Foundation, Ciba-Geigy Foundation (Japan), a Science Research Promotion Fund from the Japan Private School Promotion Foundation, and a grant from the Muscular Dystrophy Association of America. Dr. K. P. Campbell is an Investigator of Howard Hughes Medical Institute.

\section{References}

1. Miyoshi, K. 1944. Genetics and consanguineous marriage in progressive muscular dystrophy. Psychiatr. Neurol. Jpn. 48:260-273.

2. Klopfer, H. W., and C. Talley. 1958. Autosomal recessive inheritance of Duchenne type muscular dystrophy. Ann. Hum. Genet. 22:138-143.

3. Johnston, H. A. 1964. Severe muscular dystrophy in girls. J. Med. Genet. 1:79-81.

4. Penn, A. S., R. P. Lisak, and L. P. Rowland. 1970. Muscular dystrophy in young girls. Neurology. 20:147-159.

5. Walton, J. N., and D. Gardner-Medwin. 1969. Progressive muscular dystrophy and the myotonic disorders. In Disorders of Voluntary Muscle. 2nd edition. J. N. Walton, editor. Churchill Livingstone, London. 445-499.

6. Miyoshi, K., K. Saijo, Y. Kuryu, M. Yoshimatsu, Y. Oshima, M. Nakano, H. Kawai, M. Miyake, T. Okagawa, Y. Tada, et al. 1966. Proposal of "Malignant Limb-girdle" type of progressive muscular dystrophy. Clin. Neurol. (Tokyo). 6:491a. (Abstr.)

7. Miyoshi, K., Y. Tada, and H. Kawai. 1974. Genetico-clinical types of progressive muscular dystrophy, with special reference to "Malignant Limb-girdle Type". Jpn. J. Hum. Genet. 19:39-42.

8. Ben Hamida, M., M. Fardeau, and N. Attia. 1983. Severe childhood muscular dystrophy affecting both sexes and frequent in Tunisia. Muscle \& Nerve. 6:469-480

9. Ben Othmane, K., M. Ben Hamida, M. A. Pericak-Vance, C. Ben Hamida, S. Blel, S. C. Carter, A. M. Bowcock, K. Petruhkin, T. C. Gilliam, A. D. Roses, et al. 1992. Linkage of Tunisian autosomal recessive Duchenne like muscular dystrophy to the pericentrometric region of chromosome 13q. Nat. Genet. 2:315317.

10. Passos-Bueno, H. R., M. Rita, J. R. Oliveira, E. Bakker, R. D. Anderson, S. K. Marie, M. Vanzof, S. Roberds, K. P. Campbell, and M. Zatz. 1993. Genetic heterogeneity for Duchenne like muscular dystrophy (DLMD) based on linkage and 50 DAG analysis. Hum. Mol. Genet. 2:1945-1947.

11. Romero, N. B., F. M. Tomé, F. Leturcq, F. E. Kerch, K. Azibi, L. Bachner, R. D. Anderson, S. L. Roberds, K. P. Campbell, M. Fardeau, and J.-C. Kaplan. 1994. Genetic heterogeneity of severe childhood autosomal recessive muscular dystrophy with adhalin ( $50 \mathrm{kDa}$ dystrophin-associated glycoprotein) deficiency. C. R. Acad. Sci. Paris. 317:70-76.

12. Matsumura, K., F. M. S. Tomé, M. Collin, K. Azibi, M. Chaouch, J.-C. Kaplan, M. Fardeau, and K. P. Campbell. 1992. Deficiency of the 50k dystrophin associated glycoprotein in severe childhood autosomal recessive muscular dystrophy. Nature (Lond.). 359:320-322.

13. Zatz, M., K. Matsumura, M. Vainof, M. R. Passos-Bueno, R. C. M. Paranell, S. K. Marce, and K. P. Campbell. 1994. Assessment of the 50-kDa 
dystrophin-associated glycoprotein in Brazilian patients with severe childhood autosomal recessive muscular dystrophy. J. Neurol. Sci. 123:122-128.

14. Azibi, K., L. Bachner, J. S. Beckmann, K. Matsumura, E. Hanouda, M. Chaouch, A. Chaouch, R. Ai-Qwarab, A. Vignal, J. Weissenbach, et al. 1993. Severe childhood autosomal recessive muscular dystrophy with a deficiency of the $50 \mathrm{kDa}$ dystrophin-associated glycoprotein maps to chromosome 13q12. Hum. Mol. Genet. 2:1423-1428.

15. Kerch, F. E., A. Sefiani, K. Azbi, N. Boutaleb, N. Yahyaoui, A. Bentahila M.-C. Vinet, F. Leturcq, L. Bachner, J. Beckmann, et al. 1994. Linkage analysis of families with severe childhood autosomal recessive muscular dystrophy in Morocco indicates genetic homogeneity of the disease in North Africa. J. Med. Genet. 31:342-343.

16. Higuchi, I, H Yamada, H. Fukunaga, K Iwaki, R Okubo, M Nakagawa M. Osame, S. L. Roberds, T. Shimizu, K. P. Campbell, and K. Matsumura. 1994. Abnormal expression of laminin suggests disturbance of sarcolemma-extracellular matrix interaction in Japanese patients with autosomal recessive muscular dystrophy deficient in adhalin. J. Clin. Invest. 94:601-606.

17. Roberds, S. L., F. Leturcq, V. Allamand, F. Piccolo, M. Jeanpierre, R. D. Anderson, L. E. Lim, J.-C. Lee, F. M. S. Tomé, N. B. Romero, et al. 1994. Missense mutation in the adhalin gene linked to autosomal recessive muscular dystrophy. Cell. 78:625-633.

18. Chomczynski, P., and N. Sacchi. 1987. Single-step method of RNA isolation by acid guanidinium thiocyanate-phenol-chloroform extraction. Anal. Biochem. 162:156-159.

19. Frohman, M. A., M. K. Dush, and G. R. Martin. 1988. Rapid production of full-length cDNAs from rare transcripts: amplification using a single genespecific oligonucleotide primer. Proc. Natl. Acad. Sci. USA. 85:8998-9002.

20. Saiki, R. K., D. H. Gelfand, S. Stoffel, S. J. Scharf, R. Higuchi, G. T. Horn,

K. B. Mullis, and H. A. Erlich. 1988. Primer-directed enzymatic amplification of DNA with a thermostable DNA polymerase. Science (Wash. DC). 239:487-491.

21. Kaufman, D. L., and G. A. Evans. 1990. Restriction endonuclease cleavage at the termini of PCR products. Biotechniques. 9:304-306.

22. Sanger, F., S. Nicklen, and R. Coulson. 1977. DNA sequencing with chain-terminating inhibitors. Proc. Natl. Acad. Sci. USA. 74:5463-5467.
23. Smith, L. M., J. Z. Sanders, R. J. Kaiser, P. Hughes, C. Dodd, C. R. Connell, C. Heiner, S. B. H. Kent, and L. E. Hood. 1986. Fluorescence detection in automated DNA sequence analysis. Nature (Lond.). 321:674-679.

24. Gross-Bellard, M., P. Oudet, and P. Chambon. 1973. Isolation of highmolecular-weight DNA from mammalian cells. Eur. J. Biochem. 36:32-38.

25. Miyoshi, K., Y. Tada, M. Nakano, and H. Kawai. 1974. Malignant limbgirdle type of progressive muscular dystrophy as a clinical entity of the classification of muscular dystrophy. Annual report of the Research Group on Progressive Muscular Dystrophy. Ministry of Health and Welfare, Japan. II:39-49.

26. Roberds, S. L., R. D. Anderson, O. Ibraghimov-Beskrovnaya, and K. P. Campbell. 1993. Primary structure and muscle-specific expression of the $50-\mathrm{kDa}$ dystrophin associated glycoprotein (adhalin). J. Biol. Chem. 268:2373923742.

27. Ervasti, J. M., and K. P. Campbell. 1993. Dystrophin-associated glycoproteins: their possible roles in the pathogenesis of Duchenne muscular dystrophy. In Molecular and Cell Biology of Muscular Dystrophy. T. Partridge, editor. Chapman \& Hall, London. 139-166.

28. Seal, R., and S. C. Froehner. 1994. Dystrophin-associated proteins and synapse formation: is $\alpha$-dystroglycan the agrin receptor? Cell. 77:617-619.

29. Ervasti, J. M., and K. P. Campbell. 1991. Membrane organization of the dystrophin associated-glycoprotein complex. Cell. 66:1121-1131.

30. Sanes, J. R. E. Engvall, R. Butkowski, and D. D. Hunter. 1990. Molecular heterogeneity of basal laminae. Isoform of laminin and collagen IV at the neuromuscular junction and elsewhere. J. Cell Biol. 111:1685-1699.

31. Perloff, J. K., W. C. Roberts, A. C. Leon, and D. O'Doherty. 1967. Duchenne's progressive muscular dystrophy. An electrocardiographic-pathologic correlative study. Am. J. Med. 42:179-188.

32. Sanyal, S. K., R. K. F. Leung, R. C. Tierney, R. Gilmartin, and S. Pinter. 1979. Mitral valve prolapse syndrome in children with Duchenne's progressive muscular dystrophy. Pediatrics. 63:116-123.

33. McNally, E. M., M. Yoshida, Y. Mizuno, E. Ozawa, and L. M. Kunkel. 1994. Human adhalin is alternatively spliced and the gene is located on chromosome 17q21. Proc. Natl. Acad. Sci. USA. 91:9690-9694. 